\title{
POKOK-POKOK PIKIRAN MENGENAI PEMBANGUNAN KEMANDIRIAN INDUSTRI PERTAHANAN INDONESIA DALAM UNDANG-UNDANG NOMOR 16 TAHUN 2012 TENTANG INDUSTRI PERTAHANAN
}

\author{
Endro Tri Susdarwono \\ Fakultas Ilmu Sosial dan Ilmu Politik, Universitas Peradaban, Brebes \\ saniscara99midas@gmail.com
}

\begin{abstract}
Abstrak
Tujuan penelitian ini membahas mengenai deskripsi pokok-pokok pikiran mengenai pembangunan kemandirian industri pertahanan Indonesia. Penelitian ini merupakan penelitian hukum normatif, tipe penelitiannya menggunakan kajian komprehensif analitis dan pendekatannya normatif analitis. Undang-undang industri pertahanan mengatur bahwa industri pertahanan terdiri atas industri alat utama, industri komponen utama dan penunjang, industri komponen dan pendukung (perbekalan), serta industri bahan baku. Dari awal, pemerintah sudah mengatur bahwa BUMN pertahanan menjadi industri alat utama sekaligus pemandu utama (lead integrator) yang menghasilkan alat utama sistem senjata dan/atau mengintegrasikan semua komponen utama, komponen, dan bahan baku menjadi alat utama. Pertahanan Indonesia memerlukan kebijakan yang lebih progresif untuk mengejar ketertinggalan dalam penguasaan ilmu pengetahuan dan teknologi (iptek) bidang pertahanan, serta dalam rangka mewujudkan kemandirian Industri Pertahanan (Indhan). Kemandirian industri pertahanan sangat bergantung pada tiga pilar pelaku iptek, yaitu perguruan tinggi dan Lembaga Litbang, industri, dan user (TNI sebagai pengguna). Oleh sebab itu, pemerintah merumuskan kebijakan terpadu bidang iptek dan industri pertahanan yang diarahkan pada kebutuhan industri pertahanan. Pokok-pokok pikiran mengenai pembangunan kemandirian industri pertahanan Indonesia meliputi: pembentukan dan penguatan KKIP (Komite Kebijakan Industri Pertahanan), pembinaan industri utama dan pendukung, pendanaan industri pertahanan, mandiri dalam membuat/memproduksi, peningkatan kemampuan dan penguasaan teknologi industri pertahanan lewat sistem nasional, Research and development ( $\mathrm{R} \& \mathrm{D})$, kekuatan pertahanan minimum / Minimum Essential Force (MEF) dan Industri Pertahanan.
\end{abstract}

Kata kunci: industri pertahanan; alat utama sistem senjata ; pemadu utama 
p-ISSN : 2541-2345, e-ISSN : 2580-8842

\title{
THOUGHTS ON THE DEVELOPMENT OF INDEPENDENCE OF THE INDONESIAN DEFENSE INDUSTRY IN LAW NUMBER 16 OF 2012 CONCERNING THE DEFENSE INDUSTRY
}

\author{
Endro Tri Susdarwono \\ Faculty of Social Science and Political Science of Peradaban University, Brebes \\ saniscara99midas@gmail.com
}

\begin{abstract}
The purpose of this study discusses the description of the main ideas regarding the development of the independence of Indonesia's defense industry. This research is a normative legal research, the type of research uses a comprehensive analytical study and analytical normative approach. The defense industry law stipulates that the defense industry consists of the main tool industry, the main and supporting component industry, the component and support industry (supplies), and the raw material industry. From the beginning, the government has arranged that defense SOEs become the main tool industry as well as the lead guide (lead integrator) that produces the main weapons system tools and / or integrates all the main components, components, and raw materials into the main tools. Defense of Indonesia needs more progressive policies to catch up with the mastery of defense science and technology (science and technology), and in order to realize the independence of the Defense Industry (Indhan). The independence of the defense industry depends very much on the three pillars of science and technology actors, namely universities and $R \& D$ institutions, industry, and users (TNI as users). Therefore, the government formulates integrated policies in the fields of science and technology and the defense industry that are directed at the needs of the defense industry. The main ideas regarding the development of the independence of the Indonesian defense industry include: the establishment and strengthening of the KKIP (Defense Industry Policy Committee), fostering key and supporting industries, funding of the defense industry, being independent in making / producing, increasing the capability and mastery of the defense industry technology through the national system, Research and development $(R \& D)$, minimum defense force / Minimum Essential Force (MEF) and Defense Industry
\end{abstract}

Keywords: defense industry; the main weapons system tools; lead integrator 
p-ISSN : 2541-2345, e-ISSN : 2580-8842

\section{PENDAHULUAN}

\section{A. Latar Belakang}

Upaya pemenuhan kekuatan pertahanan negara pada tingkat kekuatan pokok minimal (minimum essential force) di Indonesia belum sepenuhnya dapat diwujudkan. Pembangunan kekuatan dan kemampuan pertahanan negara baru menghasilkan postur pertahanan negara dengan kekuatan terbatas (di bawah Standard Deterence). ${ }^{1}$ Pengelolaan industri strategis dan pertahanan di beberapa negara hampir selalu dihadapkan dengan tiga isu utama, yaitu: pertama, pengembangan teknologi pertahanan yang mengandalkan dua skema, memperkuat penelitian dan pengembangan industri pertahanan, dan melalui skema offset dan transfer teknologi. ${ }^{2}$

Industri Pertahanan (Indhan) merupakan salah satu komponen vital dari kemampuan pertahanan. Industri pertahanan yang kuat mempunyai dua efek utama, yakni efek langsung terhadap pembangunan kemampuan pertahanan, dan efek terhadap pembangunan ekonomi dan teknologi nasional. Dalam bidang pembangunan kemampuan pertahanan, indhan yang kuat menjamin pasokan kebutuhan alutsista dan sarana pertahanan secara berkelanjutan. Ketersediaan pasokan alat utama sistem senjata (alutsista) secara berkelanjutan menjadi prasyarat mutlak bagi keleluasaan dan kepastian untuk menyusun rencana pembangunan kemampuan pertahanan dalam jangka Panjang, tanpa adanya kekhawatiran akan faktor-faktor politik dan ekonomi, seperti embargo atau restriksi.

Indhan dapat memberikan efek pertumbuhan ekonomi dan industri nasional, yakni ikut menggairahkan pertumbuhan industri nasional yang berskala internasional, penyerapan tenaga kerja dalam jumlah yang cukup signifikan, transfer teknologi yang dapat menggairahkan sektor penelitian, dan pengembangan

1 Ahmad Jazuli, "Pembangunan Pertahanan dan Keamanan Demi Penegakan Hukum di Indonesia: Kewibawaan Suatu Negara," Jurnal Penelitian Hukum DE JURE 16, No. 2 (Juni 2016): hal 188.

2 Muradi, "Model Pendanaan Industri Pertahanan dan Peningkatan Sumber Daya Manusia," Jurnal Pertahanan 05, No. 2 (Agustus 2015): hal 213. 
p-ISSN : 2541-2345, e-ISSN : 2580-8842

sekaligus memenuhi kebutuhan sektor pendidikan nasional di bidang sains dan teknologi. ${ }^{3}$ Semakin majunya industri pertahanan maka secara otomatis akan membuka lapangan pekerjaan baru, mendorong pertumbuhan industri lain karena memiliki banyak multiple linkage dari hulu hingga hilir, mendorong percepatan kemajuan teknologi, hingga menekan besarnya anggaran yang biasanya dikeluarkan untuk mengimpor berbagai alutista dari luar negri. ${ }^{4}$ Perlu ada konsensus nasional yang berpihak kepada pengembangan kapasitas industri pertahanan nasional agar dapat memiliki kompetensi inti yang kompetitif di level regional dan global. Konsensus ini diwujudkan dalam optimalisasi kerjasama antar lembaga terkait langsung dengan pengadaan alutsista, khususnya Kementerian Pertahanan, TNI, dan pihak-pihak produsen di dalam negeri dalam rangka membangun sarana pertahanan berbasis industri pertahanan dalam negeri. ${ }^{5}$

Pembangunan kembali industri pertahanan diawali dengan pembentukan Komite Kebijakan Industri Pertahanan (KKIP) melalui Peraturan Presiden Nomor 42 Tahun 2010. Dalam perjalanannya, selama hampir dua setengah tahun, KKIP yang bergerak pada tataran kebijakan industri pertahanan telah banyak menghasilkan cetak biru atau rencana induk dan program nasional yang diperlukan bagi pengembangan industri pertahanan. Dengan mempertimbangkan pentingnya industri pertahanan bagi pembangunan kekuatan pertahanan dan sebagai industri yang diharapkan nantinya mampu mendukung perekonomian nasional, maka ditetapkan Undang-Undang Nomor 16 Tahun 2012 tentang Industri Pertahanan.

${ }^{3}$ Agus Hartanto, Kajian Kebijakan Alutsista Pertahanan dan Keamanan Republik Indonesia (Jakarta: LIPI Press, 2013), hal. 22-23.

${ }^{4}$ Pebri Tuwanto, "Politik Pembangunan Industri Pertahanan Nasional di Era Global," Jurnal Gema Keadilan 02, No. 1 (September 2015): hal 2.

${ }^{5}$ Ian Montratama, "Strategi Optimalisasi Pengadaan Sarana Pertahanan Bagi Industri Pertahanan Indonesia, ” Jurnal Pertahanan 04, No. 3 (Desember 2014): hal 79. 
Pada tahun 2012, lahirlah Undang-Undang nomor 16 tentang Industri Pertahanan yang mengatur tentang pemanfaatan dan maksimalisasi industri pertahanan dalam negeri demi mencapai target MEF Tahap I. Tujuan penguatan industri pertahanan ini adalah untuk memenuhi kebutuhan alutsista TNI guna tercapainya MEF pada tahun 2024, dan tujuan yang kedua adalah tercapainya kemandirian dalam pengadaan alutsista TNI di tahun $2029 .{ }^{6}$

Salah satu amanat Undang-Undang tersebut adalah pembentukan KKIP yang kemudian dikukuhkan dengan Keppres Nomor 59 Tahun 2013. Dengan adanya Undang-Undang Industri Pertahanan tersebut, maka keberadaan KKIP akan lebih jelas dalam mendukung pengembangan industri pertahanan Indonesia. Tugas KKIP sebagaimana diamanatkan dalam Perpres Nomor 42 tahun 2010 yang diperbaharui dengan Keppres Nomor 59 Tahun 2013 adalah menetapkan kebijakan industri pertahanan nasional pada tataran strategis, mengoordinasikan pengelolaan kebijakan industri pertahanan nasional, mengoordinasikan kerja sama internasional untuk membangun dan mengembangkan industri pertahanan nasional, melaksanakan pemantauan dan evaluasi pengelolaan kebijakan industri pertahanan, menyusun dan membentuk rencana induk industri pertahanan jangka panjang, menetapkan standar produk industri pertahanan, dan menetapkan kebijakan untuk pemenuhan kebutuhan alat peralatan pertahanan dan keamanan.

Kaitan dengan pembangunan kekuatan pokok pertahanan, tugas KKIP adalah melakukan sinkronisasi terhadap cetak biru industri pertahanan nasional, sehingga dapat sejalan dengan cetak biru pembangunan kekuatan pokok pertahanan dan cetak biru penelitian dan pengembangan (RDT\& E) alutsista di Indonesia. Dengan demikian, Badan Usaha Milik Negara (BUMN) dan Badan Usaha Milik Swasta (BUMS) yang ada dapat mensinergikan dirinya agar mampu berperan dalam mendukung pengadaan alutsista untuk kebutuhan TNI di masa mendatang. BUMN Industri Pertahanan (BUMNIP) terdiri dari lima perusahaan milik negara, yaitu PT

6 Lukman Fahmi Djarwono, "Pembangunan Industri Pertahanan Indonesia: Menuju Pemenuhan Target MEF atau Sekedar Menuju Arm Candy,” Jurnal Defendonesia 02, No. 2 (Juni 2017): hal 27. 
p-ISSN : 2541-2345, e-ISSN : 2580-8842

PINDAD, PT Dirgantara Indonesia, PT Penata Angkatan Laut (PAL), PT Dahana dan PT LEN BUMN tersebut di antaranya dapat bertindak sebagai lead integrator. Di samping itu, banyak juga BUMS yang bergerak dalam industri pertahanan untuk pembangunan alutsista di matra darat, laut, dan udara. Termasuk industri pertahanan nonalutsista adalah perusahaan makanan kaleng untuk prajurit, tekstil untuk pakaian seragam, payung udara, dan peralatan perlengkapan prajurit. ${ }^{7}$

Industri dan teknologi pertahanan, hingga saat ini masih memerlukan pengaturan untuk peningkatan pemberdayaan industri pertahanan, baik mengenai teknologi yang akan digunakan maupun biaya modal dan pembiayaan secara umum, produksi dan produktivitas dari perusahaan industri pertahnannya sendiri perlu diperhatikan secara seksama dan secara terus menerus. Biaya modal akan terkait dengan keuangan dan perbankan, baik nasional maupun internasional. Kehendak pemerintah untuk benar-benar mengembangkan dnan memajukan teknologi dan industri pertahanan harus diimplementasikan pada tingkat pragmatis, dan tidak hanya keinginan semata. Perlu adanya kebijakan dan political will yang dapat mempermudah kalangan industri pertahanan untuk maju. ${ }^{8}$

Selain itu, unsur pemasaran produk diharapkan tidak hanya dipasarkan kepada sektor pertahanan saja, namun harus dapat menembus pasar dunia. Untuk itu perlu adanya sinergitas dari berbagai pemangku kepentingan untuk meningkatkan teknologi dan industri strategi-pertahanan, sehingga dapat memberikan dukungan kepada sektor pertahanan dalam melaksanakan tugasnya mempertahankan eksistensi dan kedaulatan negara serta keselamtan bangsa, selain itu dapat menjadikan perusahaan industri pertahanan menjadi penopang kemajuan ekonomi negara dan bangsa.

Penyelenggaraan industri pertahanan sebagai penjabaran dan strategi raya (grand strategy) KKIP bertujuan untuk dapat mandiri dalam memenuhi kebutuhan

${ }^{7}$ Purnomo Yusgiantoro, Ekonomi Pertahanan : Teori dan Praktik (Jakarta : PT. Gramedia Pustaka Utama, 2014), hal. 253-254.

${ }^{8}$ Makmur Supriyatno, Tentang Ilmu Pertahanan (Jakarta : Yayasan Pustaka Obor Indonesia, 2014), hal 103. 
peralatan pertahanan dan keamanan, meningkatkan kemampuan memproduksi dan jasa pemeliharan untuk membangun kekuaan prtahanan dan keamanan yang andal. Selain itu, strategi raya ditujukan untuk memperkokoh industri pertahanan dan meningkatkan kadar teknologi industri pertahanan, penyelenggaran industri pertahanan juga bertujuan untuk meningkatkan pertumbuhan ekonomi. Hal ini bisa dilakukan melalui efek penggandaan, baik itu dengan mengembangkan bertumbuhnya industri hulu, hilir, maupun dengan membukan kesempatan bagi penyerapan tenaga kerja dan kegiatan ekonomi. ${ }^{9}$

\section{B. Perumusan Masalah}

Berdasarkan paparan di atas, penelitian ini berusaha untuk mencari jawaban atas pertanyaan bagaimana pokok-pokok pikiran mengenai pembangunan kemandirian industri pertahanan Indonesia dalam Undang-Undang Nomor 16 Tahun 2012 ?

\section{Metode Penelitian/Landasan Teoritis}

Penelitian ini termasuk penelitian hukum normatif yang hanya menggunakan data sekunder. Tipe penelitian hukumnya adalah kajian komprehensif analitis terhadap bahan hukum primer dan bahan hukum sekunder. Hasil kajian dipaparkan secara lengkap, rinci, jelas, dan sistematis sebagai karya ilmiah. Metode pendekatan yang digunakan adaah metode pendekatan yuridis normatif. Karena penelitian ini termasuk penelitian hukum normatif, pendekatannya menggunakan pendekatan normatif analitis, melalui pendekatan ini, artikel ini membahas mengenai aspekaspek hukum yang berkaitan dengan industri pertahanan berdasarkan UndangUndang Nomor 12 Tahun 2012 tentang Industri Pertahanan dengan mengikuti langkah-langkah sebagai berikut :

1) mengidentifikasi sumber hukum yang menjadi dasar rumusan masalah;

2) mengidentifikasi pokok bahasan dan subpokok bahasan yang bersumber dari rumusan masalah;

3) mengidentifikasi dan menginventarisasi ketentuan-ketentuan normatif bahan hukum primer dan bahan hukum sekunder berdasarkan rincian subpokok bahasan;

\footnotetext{
${ }^{9}$ Yusgiantoro, op.cit., hal 254-255.
} 
4) mengkaji secara komprehensif analitis bahan hukum primer dan bahan hukum sekunder guna menjawab permasalahan yang telah dirumuskan;

5) hasil kajian sebagai jawaban permasalahan dideskripsikan secara lengkap, rinci, jelas, dan sistematis dalam bentuk laporan hasil penelitian atau karya tulis ilmiah.

Spesifikasi penelitian dalam penelitian ini menggunakan deskriptif analitis, yaitu menguraikan hasil-hasil penelitian sesuai dengan permasalahan dan tujuan yang akan dicapai serta menganalisanya dari segi peraturan perundangan yang berlaku. Metode pengumpulan data menggunakan : studi pustaka ( bibliography study), dokumen (document study), dan studi arsip (file or record study).

Analisis data (analyzing), yaitu menguraikan data dalam bentuk kalimat yang baik dan benar, sehingga mudah dibaca dan diberi arti (diinterpretasikan) sehingga hasil analisis data memudahkan pengambilan kesimpulan secara induktif. Bahan hukum (data) hasil pengolahan tersebut dianalisis secara kualitatif dan kemudian dilakukan pembahasan. Berdasarkan hasil pembahasan kemudian diambil kesimpulan sebagai jawaban terhadap permasalahan yang diteliti.

\section{PEMBAHASAN}

Upaya pengembangan Industri Pertahanan merupakan bagian dari penyelenggaraan pertahanan secara utuh, serta bagian dari pembangunan nasional secara menyeluruh. Konsep pengembangan Indhan melibatkan pihak pengguna (Kementerian Pertahanan (Kemhan) dan TNI), pihak yang memproduksi, perancang, penguji, peneliti yang kompeten, serta perencana yang tepat dalam kerangka konsep Tiga Pilar Pelaku Industri Pertahanan. Konsep tiga pilar pelaku Indan memadukan perguruan tinggi dan komunitas Litbang yang memiliki kemampuan untuk melakukan pengkajian dan pengembangan iptek pertahanan, Industri strategis yang mendayagunakan iptek, serta Kemhan dan TNI sebagai pengguna. Kemhan dan TNI selaku pengguna tidak hanya menerima dan menggunakan hasil produksi dari industri strategis, tetapi juga terlibat dalam pengembangan desain sampai menghasilkan prototipe menurut kebutuhan. Peran 
p-ISSN : 2541-2345, e-ISSN : 2580-8842

litbang sebagai jembatan antara pengguna dan industri sangat penting dalam mewujudkan kemandirian Indhan teknologi. ${ }^{10}$

Proses kemandirian ini tidak terlepas dari peran Indhan sebagai pelaku dalam pemanfaatan, penguasaan dan pengembangan teknologi pertahanan yang terpilih. Kondisi ini pada akhirnya akan meningkatkan kekuatan nasional (National Power) dan posisi tawar (Bargaining Position) dalam rangka membangun kekuatan pertahanan yang handal. Oleh sebab itu, program Revitalisasi Indhan sangat perlu dilakukan, khususnya komitmen, konsistensi dan kontinuitas dari semua pemangku kepentingan. Revitalisasi Indhan memerlukan sinergitas dan integritas segenap pemangku kepentingan (stake holders), yakni pengguna, produsen dan pemerintah.

Upaya mewujudkan Revitalisasi Industri Pertahanan ini, memerlukan suatu penataan dan pengaturan yang dapat lebih menjembatani keserasian dalam memprioritaskan kepentingan pertahanan dengan kepentingan nasional lainnya melalui perangkat pengaturan yang sederhana, tegas dan kenyal, serta wujud pembangunan sistem industri yang solid, danat meningkatkan efektifitas dan

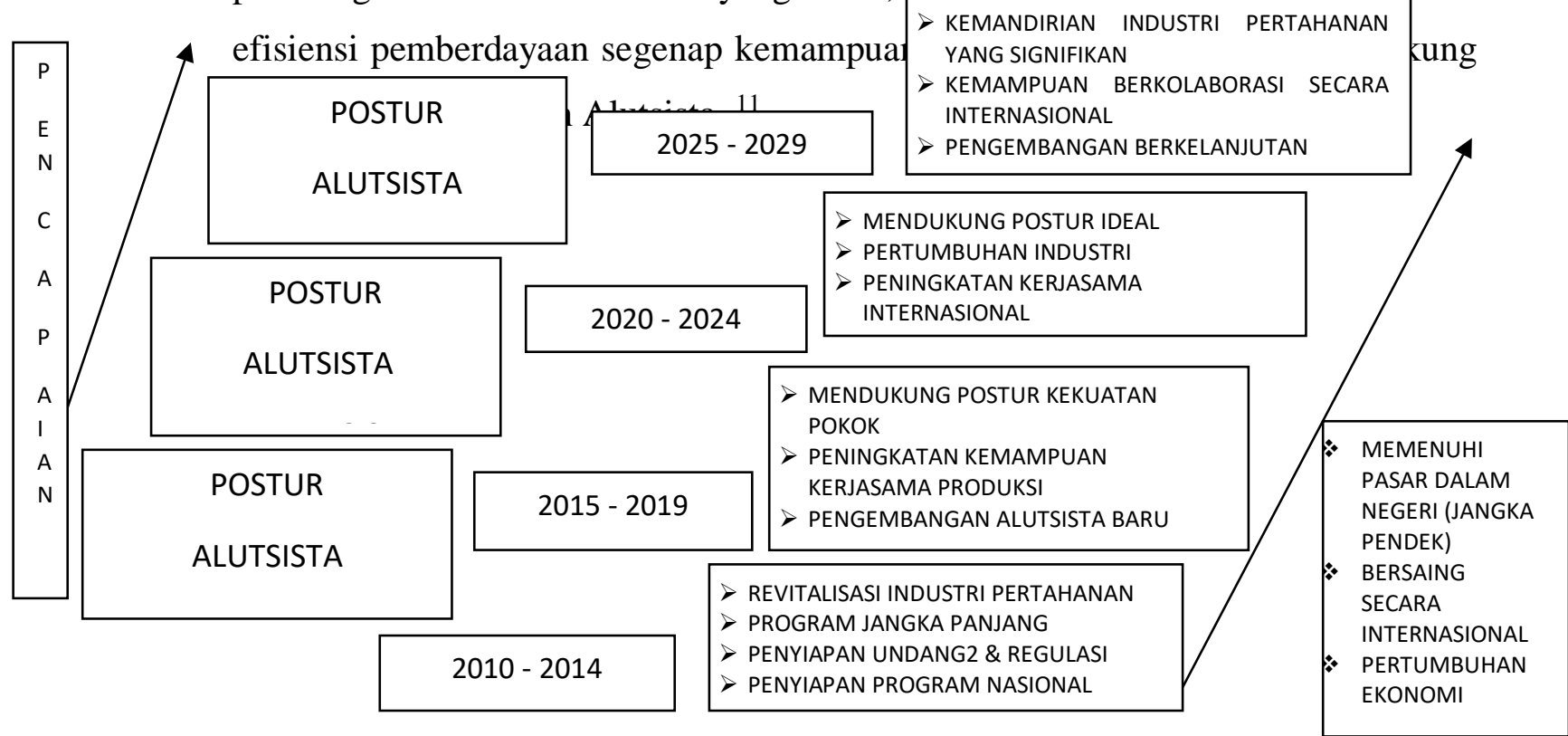

${ }^{10}$ Hartanto, op.cit., hal 30.

${ }^{11}$ Rapat harmonisasi RUU Revitalisasi Indhan, 2010 
Gambar 1. Cetak Biru Pembangunan Kekuatan Pertahanan dan Pembangunan Industri (Yusgiantoro, 2014)

Gambar 1 menunjukkan cetak biru pembangunan kekuatan pertahanan yang sejalan dengan pembangunan industri pertahanan Indonesia. Misi utamanya adalah dapat memenuhi pasar domestik kebutuhan alutsista pertahanan, mampu bersaing secara internasional dan dapat mendukung pertumbuhan ekonomi nasional. Dalam setiap tahapan pembangunan industri pertahanan nasional tercantum sasaran yang perlu dicapai dalam jangka waktu masing-masing lima tahun. Pada periode tahun 2010-2014, praktis seluruh sasaran dapat dicapai, yaitu revitalisasi industri pertahanan, dimana sebagian besar Badan Usaha Milik Negara (BUMN) dan Badan Usaha Milik Swasta (BUMS) sudah mulai tumbuh; cetak biru untuk litbabng, Industri Pertahanan (Indhan) dan pembangunan kekuatan pertahanan (Bangkuathan); UU Industri Pertahanan yang sudah dapat diselesaikan dan penjabarannya dalam bentuk peraturan yang lebih rendah; dan program nasional yang meliputi beberapa alutsista nasional, seperti kapal selam, perusak kawal rudal (PKR), radar, pesawat tempur KFX/IFX, tank kelas menengah (medium battle tank). ${ }^{12}$

\section{Pembentukan dan Penguatan KKIP (Komite Kebijakan Industri Pertahanan)}

Di Indonesia, Komite Kebijakan Industri Pertahanan yang disingkat dengan KKIP dibentuk berdasarkan Pasal 18 Undang-Undang Nomor 16 Tahun 2012 tentang Industri Pertahanan, yang memiliki tugas untuk mengkoordinasikan kebijakan nasional dalam perencanaan, peumusan, pelaksanaan, pengendalian, sinkronisasi, dan evaluasi Industri Pertahanan (Pasal 16 UU No. 16 Tahun 2012). Secara rinci, Peraturan Presiden RI Nomor 59 Tahun 2013 menjelaskan tentang Organisasi, Tata Kerja, dan Sekretariatan KKIP.

Keberadaan UU Nomor 16 Tahun 2012 dan Peraturan Presiden RI Nomor 59 Tahun 2013 tentang Organisasi, Tata Kerja, dan Sekretariat KKIP arah kebijakan industri pertahanan RI semakin jelas dan terkontrol karena idealnya telah dibuat

\footnotetext{
12 Yusgiantoro, op.cit., hal259.
} 
suatu blue print bagaimana sebenarnya pengembangan industri pertahanan ke depan telah dibuat, tentunya dengan berbagai pertimbangan dan analisis yang mendalam, dengan membuat suatu kerangka kerja atau framework of analysis untuk menentukan visi dan arah dari industri pertahanan Indonesia.

Sebagaimana diatur dalam Perpres Nomor 59 Tahun 2013, KKIP mempunyai beberapa fungsi antara lain :

a. Merumuskan kebijakan nasional yang bersifat strategis;

b. Menyusun dan membentuk rencana induk, jangka menengah, dan Panjang;

c. Mengoordinasikan pelaksanaan dan pengendalian kebijakan nasional;

d. Menetapkan kebijakan pemenuhan kebutuhan alat pertahanan dan keamanan;

e. Mengoordinasikan kerja sama luar negeri dalam rangka memajukan dan mengembangkan industri pertahanan;

f. Melakukan sinkronisasi penetapan kebutuhan alat peralatan perthanan antara pengguna dan pihak industri;

g. Menetapkan standar industri pertahanan;

h. Merumuskan kebijakan pendanaan dan/atau pembiayaan;

i. Merumuskan mekanisme penjualan dan pembelian alat peralatan pertahanan dan keamanan hasil industri pertahanan dari luar ngeri;

j. Melaksanakan pemantauan dan evaluasi pelaksanaan kebijakan secara berkala. Di Indonesia, Komite Kebijakan Industri Pertahanan (KKIP) terus mendorong upaya dan proses menuju transparansi pengadaan dan kebutuhan militer. Dalam Pasal 21 Undang-Undang Nomor 16 Tahun 2012 tentang Industri Pertahanan, salah satu tugas dan wewenang KKIP adalah melakukan sinkronisasi penetapan kebutuhan alpalhankam antara pengguna dan industri pertahanan (Pasal 21, UU No. 16 Tahun 2012). Biasanya, proses yang ditempuh adalah KKIP mengundang Tentara Nasional Indonesia (TNI) dan badan usaha milik negara (BUMN) pertahanan untuk duduk bersama. Dalam pertemuan itu akan dibahas jenis alpalhankam yang dibutuhkan TNI dan bagaimana industri bisa memenuhinya.

Sejak keluarnya Undang-Undang Nomor 16 Tahun 2012 tentang Industri Pertahanan, Pemerintah memutuskan kebijakan tegas untuk membatasi impor produk pertahanan. Impor alpalhankam hanya dibolehkan jika peralatan atau sistem 
p-ISSN : 2541-2345, e-ISSN : 2580-8842

senjata dimaksud belum dapat dibuat oleh industri pertahanan dalam negeri. Namun demikian, terdapat beberapa syarat yang telah ditentukan dalam Pasal 43 UndangUndang Nomor 16 Tahun 2012 :

1. Prosesnya langsung antar pemerintah atau kepada pabrikan.

2. Mengikutsertakan partisipasi industri pertahanan.

3. Wajib melakukan alih teknologi.

4. Harus disertai jaminan tidak ada potensi embargo, kondisionalitas politik, dan hambatan penggunaan alpalhankam dalam upaya mempertahankan kedaulatan negara.

5. Ada imbal dagang, kandungan local dan/ atau offset paling rndah 35 persen, dengan peningkatan 10 persen setiap 5 tahun.

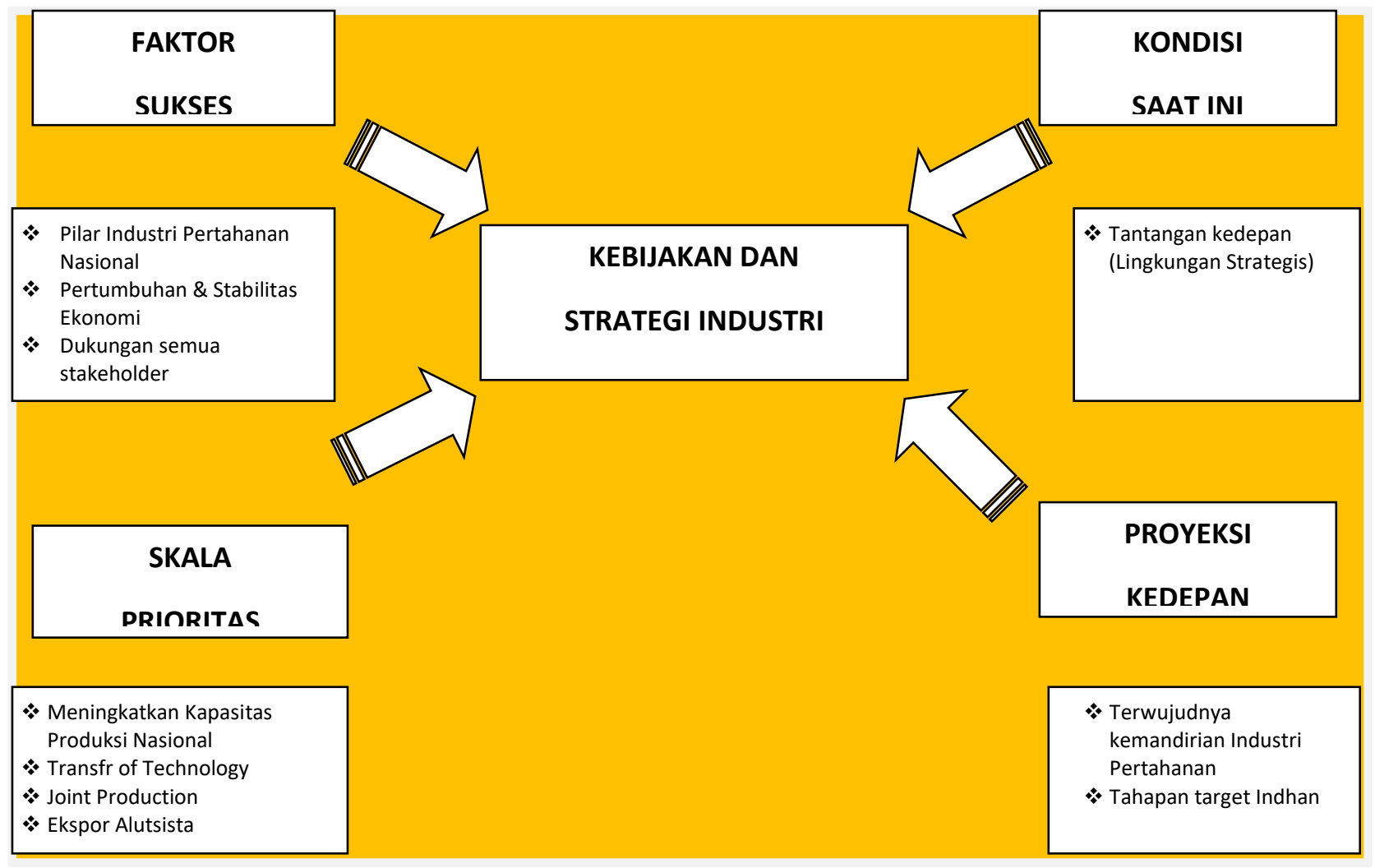

Gambar 2. Kebijakan dan Strategi Industri Pertahanan (Yusgiantoro, 2014)

Adapun kebijakan kontrak pengadaan pemerintah sudah menunjukkan keberpihakan dengan penunjukan langsung yang disebut penugasan kepada BUMN produsen alat utama. Dasarnya adalah Undang-Undang Nomor 16 Tahun 2012 
tentang Industri pertahanan yang telah memberikan kewenangan kepada Pemerintah untuk menentukan teknologi dan produk alpalhankam yang akan dikuasai dan dikembangkan. Setelah ditentukan, KKIP yang mengoordinasi kerja sama luar negeri serta merumuskan mekanisme penjualan dan pembelian alpalhankam ke dan dari luar negeri. Biasanya untuk program sinergi joint production atau joint development yang bertujuan menciptakan transfer teknologi sebagai bagian proses penyiapan produk masa depan.

Gambar 2 menjelaskan bagaimana kebijakan dan strategi industri pertahanan yang dikembangkan dalam rangka menuju kemandirian. Dalam mengembangkan formulasi kebijakan dan strategi industri pertahanan ini dipertimbangkan kondisi saat ini, faktor sukses, skala prioritas, dan proyeksi ke depan. Kondisi saat ini terutama dilihat dari perkembangan lingkungan strategis, fokus sektor pertahanan adalah pembangunan kekuatan pertahanan dalam jangka panjang. Hal itu tertuang dalam rencana pembangunan jangka panjang, di mana pembangunan kekuatan jangka pendek tiap tahun dan jangka menengah lima tahunan sudah termasuk di dalamnya. Dalam rencana pembangunan jangka panjang diharapkan akan terbentuk kekuatan ideal dengan jembatan pembangunan kekuatn pokok sampai dengan tahun 2024. Berdasarkan pembangunan kekuatan pokok sampai dengan tahun 2024 tersebt, dikembangkan kebijakan dan strategi industri pertahanan yang sejalan dengan pembangunan kekuatan pertahanan. Ini dilakukan karena embangunan jangka panjang industri pertahanan secara khusus dirancang untk menopang pencaaian kekuatan ideal. Di samping adanya keinginan untuk memiliki industri pertahanan yang kuat, kebijakan industri petahann juga dapat memberikan kontribusi terhadap sektor pertahanan di kawasan regional dan internasional pada umumnya lewat ekspor alutsista. ${ }^{13}$

\section{Pembinaan Industri Utama dan Pendukung}

Undang-Undang Nomor 16 Tahun 2012 tentang Industri Pertahanan mengatur bahwa industri pertahanan terdiri atas industri alat utama, industri komponen utama dan penunjang, industri komponen dan pendukung (perbekalan), serta industri

${ }^{13}$ Yusgiantoro, op.cit., hal 264-265. 
bahan baku. Dari awal, pemerintah sudah mengatur bahwa BUMN pertahanan menjadi industri alat utama sekaligus pemandu utama (lead integrator) yang menghasilkan alat utama sistem senjata dan/atau mengintegrasikan semua komponen utama, komponen, dan bahan baku menjadi alat utama. Pemerintah tidak lagi membuka kesempatan berinvestasi bagi sektor swasta pada industri alat utama. Oleh karena, berdasarkan Pasal 52 Undang-Undang Nomor 16 Tahun 2012 menegaskan bahwa modal atas industri alat utama seluruhnya dimiliki negara. Sedangkan modal atas aindustri komponen utama/penunjang, industri komponen/pendukung (perbekalan), dan industri bahan baku, yang merupakan badan usaha milik negara, paling rendah 51 (lima puluh satu) persen dimiliki negara.

Terdapat beberapa BUMN yang posisinya harus menjadi pemandu utama. BUMN yang sudah ada, seperti PT Dirgantara Indonesia (DI), dapat menjadi lead integrator untuk pesawat tempur, pesawat terbang, atau helikopter. Dengan demikian, BUMN tersebut akan menjadi pemadu utama cluster indstri pertahanan sub-cluster pesawat terbang, baik fixed-wing maupun rotary, baik tempur maupun angkut. Sedangkan, PT Pindad akan menjadi pemadu utama untuk produk senjata dan kendaraan tempur. Pindad akan menjadi lead integrator cluster industri pertahanan sub-cluster kendaraan tempur dan senjata. Adapun PT PAL menjadi pemimpin untuk cluster industri pertahanan kapal kombatan, sub-cluster kapal perang atas air dan kapal selam. ${ }^{14}$

Industri komponen utama/penunjang boleh BUMN, tapi boleh Badan Usaha Milik Swasta (BUMS). Industri komponen utama/penunjang memproduksi komponen utama tau mengintegrasikan komponen atau suku cadang dengan bahan baku menjadi komponen utama alat peralatan pertahanan keamanan (alpalhankam) atau platform sistem alutsista. Sedangkan industri komponen/pendukung (perbekalan) memproduksi suku cadang untuk alat utama sistem senjata, suku cadang untuk komponen utama, dan/atau yang menghasilkan produk perbekalan.

\footnotetext{
${ }^{14}$ Silmy Karim, Membangun Kemandirian Industri Pertahanan Indonesia (Jakarta : Kepustakaan Populer Utama, 2014), hal 235.
} 
p-ISSN : 2541-2345, e-ISSN : 2580-8842

Adapun industri bahan baku memproduksi bahan baku yang akan digunakan oleh industri alat utama, industri komponen utama/penunjang, dan industri komponen/pendukung (perbekalan). ${ }^{15}$

Kondisi saat ini, BUMN yang lain belum diarahkan menjadi bagian dari cluster penunjang dan pendukung. PT Inka, yang memproduksi gerbong penumpang dan barang; PT Boma Bisma Indra, yang memproduksi peralatan pembangkit tenaga listrik dan peralatan pabrik; serta PT Dok Perkapalan Koja Bahari, PT Dok Perkapalan Surabaya, dan PT Industri Kapal Indonesia, yang memproduksi landing ship, kapal patrol, kapal kargo, kapal ikan, kapal tunda, dan repowering KRI, harus disinergikan untuk menciptakan cluster industri alat utama. Melihat keterbatasn BUMN pertahanan, upaya menciptakan cluster industri pertahanan harus melibatkan BUMS. ${ }^{16}$

Saat ini ada beberapa BUMS produsen alpalhankam, yakni CV Sari Bahari, yang memproduksi bom udara latih, PT Daya Radar Utama (kapal angkut tank), PT Lundin Invest (wahana kapal cepat rudal trimaran dan catamaran), PT Palindo (wahana kapal cepat rudal 40 meter dan kapal patrol), PT Sentra Surya Ekajaya (rantis), PT Infoglobal (avionics), PT CMI (radar, VSAT untuk ground segment satelit), PT Langit Biru (payung udara orang), PT Saba Wijaya (helm antipeluru), PT Maju Mapan (tenda lapangan), PT Sritex dan PT Famatex (pakaian dinas, kain pakaian dinas, kain), serta PT Jangkar (ransum/makanan). ${ }^{17}$

Masalahnya, kebanyakan BUMS ini belum diarahkan menjadi bagian dari cluster industri pertahanan yang mampu memproduksi komponen penjunjang dan pendukung atau bahan baku. Seperti BUMN non-pemadu utama, kebanyakan BUMS tidak memproduksi barang yang sesuai untuk menyusun cluster yang terpadu. Sebagian BUMS ini memproduksi barang jadi yang berada di luar cluster industri yang diharapkan atau memproduksi alpalhankam yang mirip atau overlapping dengan produk industri alat utama sebagai lead integrator.

15 Ibid.

${ }^{16}$ Ibid, hal 236-237.

${ }^{17}$ Ibid, hal 237-238. 
p-ISSN : 2541-2345, e-ISSN : 2580-8842

\section{Pendanaan Industri Pertahanan}

Sejauh mana komitmen dan peran pemerintah sebagai pelanggan industri pertahanan bisa dilihat pertama dan utama dari pendanaan. Keinginan pemerintah untuk tetap mempertahankan kepemilikan di industri pertahanan tentu harus diiringi dengan komitmen pendanaan yang jelas. Ada beberapa komitmen pendanaan pemerintah terhadap industri pertahanan seperti diatur menurut UndangUndang Nomor 16 Tahun 2012. Kerangka besarnya, pemerintah menetapkan keranga pembiayaan jangka Panjang untuk industri pertahanan milik negara melalui Anggaran Pendapatan dan Belanja Negara (APBN) atau instrument pembiayaan lain. ${ }^{18}$

Pemerintah juga bisa memberikan insentif fiskal, termasuk pembebasan bea masuk dan pajak, jaminan, pendanaan, dan/atau pembiayaan kepada industri pertahanan atas pertimbangan KKIP (Pasal 41, UU No. 16 Tahun 2012). Bentuknya bisa bermacam-macam. Untuk penjualan produk industri pertahanan, pemerintah dapat menyediakan fasilitas pinjaman dalam negeri dan memberikan jaminan pinjaman kepada pihak lain. Jaminan juga bisa diberikan pemerintah kepada perbankan dan lembga keuangan lain yang mendukung pembiayaan pengembangan dan pemanfaatan industri pertahanan. ${ }^{19}$

Selain aspek penjualan, guna kepentingan pemasaran alat peralatan pertahanan keamanan (alpalhankam) ke luar negeri, Pemerintah dapat memberikan dukungan pembiayaan. Kebijakan ekspor juga bisa menjadi indikasi seberapa jauh negara mendukung industri pertahanan. Sebab, ekspor senjata ke negar lain bisa ikut meningkatkan hubungan bilateral, memproyeksikan soft power negara pengekspor, dan yang tidak kalah penting membantu industri pertahanan memperoleh pendapatan dari ekspor. Pemerintah juga bisa memberikan preferensi harga terhadap biaya kemahalan atas produk yang dihasilkan industri pertahanan.

Hal yang penting adalah Pemerintah dapat melakukan penyertaan modal untuk pembangunan dan peningktan kapasitas produksi industri pertahanan milik negara.

\footnotetext{
${ }^{18}$ Pasal 59 Undang-Undang Nomor 16 Tahun 2012.

${ }^{19}$ Pasal 41 Undang-Undang Nomor 16 Tahun 2012.
} 
Pemerintah sendiri sudah memberikan dukungan pendanaan lewat penyertaan modal negara (PMN) kepada tiga BUMN industri pertahanan yang menjadi pemandu utama. PT DI, misalnya, menerima PMN sebesar Rp4,3 triliun sampai 2012, dengan Rp2,9 triliun di antaranya merupakan penyertaan non-tunai. Sedangkan, Pindad dan PAL menerima masing-masing Rp300 miliar dan Rp1,25 triliun (Komite Kebijakan Industri Pertahanan (KKIP). ${ }^{20}$

Pemerintah sendiri mengatur bahwa modal atas industri alat utama seluruhnya dimiliki oleh negara. Sedangkan modal atas industri komponen utama/penunjang, industri komponen/pendukung (perbekalan), dan industri bahan baku, yang merupakan badan usaha milik negara, paling rendah 51 persen dimiliki negara. ${ }^{21}$

Apabila industri pertahanan memutuhkan komonen dan peralatan produksi yang belum dapat dipenuhi di dalam negeri, Pemerintah pun dapat memberikan insentif fiskal, termasuk pembebasan bea masuk dan pajak, terhadap komponen dan peraltan produksi yang diimpor. Permasalahannya adalah karena kebijakan tersebut tidak berada di bawah kontrol langsung dari pengambil kebijakan pertahanan dan melibatkan banyak pemangku kebijakan (stakeholder) lain. Sehingga, perlu upaya koordinasi dan sinkornisasi untuk menyamakan persepsi semua pemangku kepentingan terhadpa kebijakan pengembangan industri pertahanan. Mekanisme untuk menyelesaikan kemungkinan perbedaan pandangan dalam pemberian fasilitas pendanaan bagi industri pertahanan adalah menyelesaikan peraturan pelaksanaan yang diamanatkan dalam Undang-Undang Industri Pertahanan, agar mekanisme pemberian fasilitas memiliki regulasi yang jelas dan pasti bagi semua pihak. $^{22}$

\section{Mandiri dalam Membuat/Memproduksi}

Mandiri dalam membuat merupakan bentuk kemandirian yang paling penting.

Dari sisi politik, sebagai negara netral yang tidak memiliki konflik serius dengan

\footnotetext{
${ }^{20}$ Paparan Menteri Pertahanan Selaku Ketua Harian KKIP pada Sidang Pertama KKIP”, materi presentasi (Surabaya, 12 Maret 2014)

${ }^{21}$ Pasal 52 Undang-Undang Nomor 16 Tahun 2012.

22 Pasal 50 Undang-Undang Nomor 16 Tahun 2012.
} 
negara lain dan tidak mengalami tekanan internasional, Indonesia memunyai keleluasaan tersendiri untuk mewujudkan kemandirian dalam membuat peralatan pertahanan. Di luar adanya berbagai barrier seperti minimnya sumber daya (resources), baik secara keuangan, infrastruktur, SDM, maupun teknologi, faktor keleluasaan tersebut harus terus dimanfaatkan dengan baik.

Sebenarnya kemandirian dalam membuat ini sudah lama ada dan dimanfaatkan Indonesia. Berbagai pelaku industri pertahanan di Indonesia terus memproduksi berbagai produk pertahanan hingga kini, terutama melalui skema-skema kerja sama, seperti kerja sama Airbus dengan PT DI dan PT Pindad dengan FNSS Turki. ${ }^{23}$

Kemandirian dalam membuat peralatan pertahanan harus terus dimanfaatkn dan dikembangkan. Dengan membuat sendiri alat-alat petahanan, Indonesia akan mendapat berbagai keuntungan, dari keuntungan ekonomi berupa munculnya cluster-cluster industri pertahanan yang akan membantu mendorong pertumbuhan ekonomi, menyediakan banyak lapangan kerja, dan meningkatkan kemampuan teknologi, hingga keuntungan kekuatan pertahanan Indonesia (kekuatannya menjadi lebih tidak mudah dibaca disbanding jika menggunakan berbagai alutsista dari negara lain.

Kemandirian dalam membuat alat-alat pertahanan sendiri adalah tujuan besar yang hendak dicapai bangsa Indonesia. Meski kemandirian total sulit dicapai, langkah menuju kemandirian industri pertahanan kita tidak boleh surut. Pasal 50 ayat 1 Undang-Undang Nomor 16 Tahun 2012 tentang Industri Pertahanan menyatakan bahwa pembangunan industri pertahanan mengutamakan komponen dan peralatan produksi dari dalam negeri. Amanat undang-undang ini harus dilaksanakan dengan baik dan penuh komitmen. Kemampun membuat peralatan pertahanan sendiri tidak hanya akan membuat Indonesia mendapatkan keuntungankeuntungan seperti yang telah disebut di atas, tapi juga akan membawa Indonesia sebagai negara yang disegani dalam pergaulan internasional.

\section{Peningkatan Kemampuan dan Penguasaan Teknologi Industri Pertahanan} Lewat Sistem Nasional.

\footnotetext{
${ }^{23}$ Karim, op.cit., hal 83.
} 
Undang-Undang Nomor 16 Tahun 2012 tentang Industri Prtahanan mengamanatkan peningkatan kemampuan dan penguasaan teknologi industri pertahanan yang dilakukan melalui penelitian dan perekayasaan lewat sistem nasional. Dalam Pasal 28 ayat (1) Undang-Undang Nomor 16 Tahun 2012 yang menegaskan bahwa penguasaan teknologi memang menjadi salah satu kunci penting dalam industri pertahanan dan masalah pertahanan negara secara umum. Teknologi adalah aspek yang bisa membedakan kemampuan pertahanan suatu negara dengan negara lain. Apabila penguasaan teknologi dapat dilakukan oleh para pelaku industri pertahanan di Indonesia, maka hal tersebut akan menjadi keuntungan besar bagi kekuatan pertahanan Indonesia.

Penguasaan teknologi yang terus berkembang akan memberikan keuntungan jangka panjang dalam bentuk keunggulan peralatan pertahanan dibandingkan dengan negara lain. Hal ini telah dibuktikan oleh negara-negara maju, yang memiliki pelaku industri pertahanan yang juga maju dan menguasai teknologi canggih. Penguasaan teknologi dalam bentuk dual-use technologies, yaitu pengembangan teknologi untuk dua tujuan, yakni tujuan komersial (damai) dan tujuan pertahanan (militer dan keamanan), akan membuat teknologi dapat terus berkembang. ${ }^{24}$ Hal ini karena pengembangan teknologi kemudian tidak hanya didukung oleh negara, tapi juga oleh sektor privat dan publik seperti mahasiswa dan peneliti. Pengalaman negara seperti Amerika Serikat, yang mengembangkan teknologi untuk kepetingan komresial dan pertahanan, sejak Perang Dunia II merupakan bukti paling nyata bahwa teknologi akan merupakan keuntungan penting dalam kemandirian industri pertahanan.

Penguasaan hierarki tertinggi dalam teknologi pertahanan, negara kuat seperti Amerika Serikat mampu menjadi negara yang paling kuat sistem pertahanannya. Saat ini, dengan kecenerungan penyebaran dan penguasan teknologi dari barat ke timur, negara-negara Asia seperti Indonesia mempunyai kesempatan untuk terus

${ }^{24}$ Kathleen A. Walsh, "The Role, Promise, and Challenges of Dual-Use Technologies in Nasional Defense", dalam Richard A. Bitzinger (editor), The Modern Defense Industri, ABC-CLIO, LLC, California, 2009, hal. 123-145. 
mengembangkan teknologi pertahanannya. Dengan adanya kemampuan pelaku industri pertahanan dalam negeri dalam hal kepemilikian dan penguasaan teknologi sendiri, kemampuan pertahanan Indonesia juga akan meningkat. Sebab, dengan kemandirian teknologi, kekuatan pertahanan Indonesia akan menjadi tidak mudah terbaca oleh negara-negara lain. ${ }^{25}$

Terkait dengan sumber daya manusia, sebagaimana amanat Undang-Undang Nomor 6 Tahun 2012 tentang Industri Pertahanan Pasal 34 ayat 1 menyatakan bahwa pemerintah, pengguna dan industri pertahanan harus menyiapakan sumber daya manusia yang diperlukan untuk menguasai teknologi pertahanan dan keamanan yang sarat dengan teknologi tinggi dan ilmu terapan industri pertahanan. Gambar 3 menggambarkan alutsista yang mampu dibangun industri pertahanan Indonesia, baik sekarang, maupun yang akan datang, berdasarkan tingkat pengembangan dan tingkat kesiapan teknologi. Pengembangan alutsista ini dilakukan dengan skema kerjasama riset dan kerja sama produksi, di mana beberapa alutsista sudah dapat dikembangkan, diproduksi dan bankan tidak hanya dipakai untuk kebutuhan dalam negeri, tetapi juga dapat diekspor. Berbagai alutsista berdasarkan tingkat pengembangan dan tingkat kesiapan teknologinya seperti diringkas dalam gambar $3{ }^{26}$

${ }^{25}$ Karim, op.cit., hal 92-93.

${ }^{26}$ Yusgiantoro, op.cit., hal 260. 
p-ISSN : 2541-2345, e-ISSN : 2580-8842

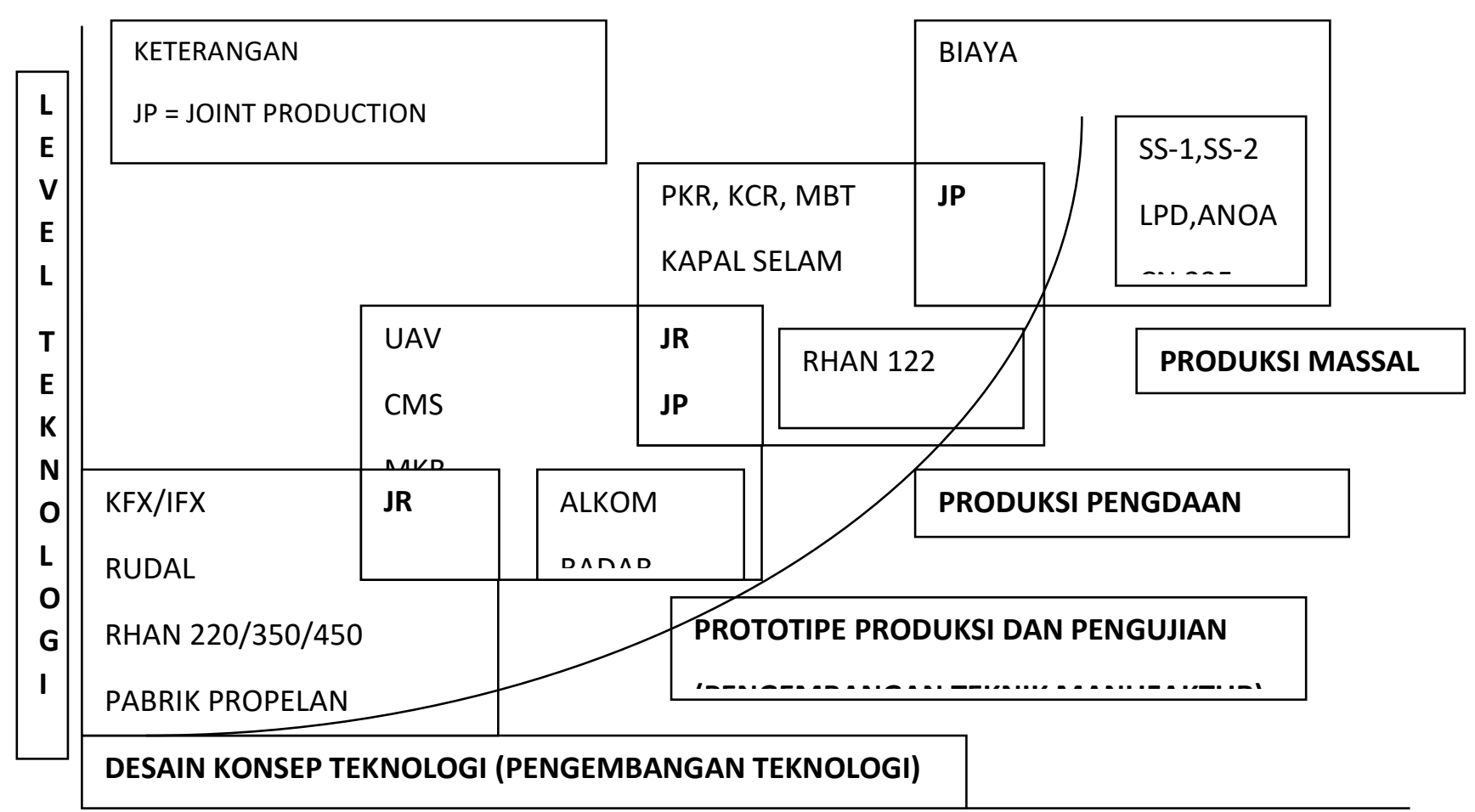

LEVEL PENGEMBANGAN

Gambar 3. Tahapan Pengembangan Industri Pertahanan Berdasarkan Alutsista Tertentu (Yusgiantoro, 2014)

Salah satu persoalan yang kini dihadapi Indonesia adalah masih lambatnya perkembangan industri pertahanan dalam negeri. Akibatnya, para pelaku industri pertahanan di dalam negeri belum bisa menampung SDM berkualitas yang telah belajar secara formal di negara-negaa maju. Dalam beberapa kasus,seperti yang terjadi di PT Dirgantara Indonesia, ada SDM-SDM berkualitas asal Indonesia yang bahkan diambil oleh perusahaan alat pertahanan di luar negeri. Beberapa warga negara Indonesia yang telah menyelesaikan Pendidikan tinggi di bidang industri pertahanan terpaksa juga bekerja di perusahaan-erusahaan kelas dunia seperti Boeing karena industri pertahanan di dalam negeri belum memberikan tempat yang layak. $^{27}$

${ }^{27}$ Ibid, hal 93-94. 
Berdasarkan Pasal 36 Undang-Undang Nomor 16 Tahun 2012 tentang Industri Pertahanan Pemerintah juga wajib mendorong kerja sama di antara semua unsur kelembagaan ilmu pengetahuan dan teknologi dalam pengembangan jaringan informasi, ilmu pengetahuan pertahanan dan keamanan, serta teknologi industri pertahanan..

\section{Research and Development (R \& D).}

Pertahanan adalah sektor yang sangat technology-intensive, peran pemerintah untuk membantu aktivitas dan pendanaan R\&D buat pengembangan teknologi yang aplikatif untuk pertahanan sangat besar dampaknya. Wajar saja, karena perang sejatinya adalah usaha untuk mengeksploitasi keunggulan disbanding musuh. Salah satunya adalah keunggulan teknologi. Karena itu, upaya R\&D yang intensif adalah syart penting untuk memastikan keunggulah teknologi pertahanan.

Amerika Serikat (AS) adalah contoh nyata negara yang power-nya terletak pada keunggulah R \& D untuk militer. Bahkan seluruh strategi pertahanan, kebijakan luar negeri, dan prinsip keamanan nasional AS di bangun atas basis ideologi untuk mempertahankan superioritas teknologi yang substansial teerhadap negara musuh dan sekutu. Paradigma ini lahir semasa Perang Dingin. Oleh karena jumlah tentara AS jauh lebih sedikit apabila dibandingkan dengan Uni Soviet. Maka, AS mengimbanginya dengan berusaha unggul dari sisi teknologi. dan kebijakan ini tetap dianut sampai sekarang.

Manfaat dari pendanaan yang masih untuk R\&D ini dirasakan sektor komersial berupa efek tumpah (spillover effect) dan spin-off produk komersial hasil turunan produk militer. Computer yang kita kenal sekarang, contohnya, sebenarnya berasal dari proyek Electronic Numerical Integrator and Computer (ENIAC) yang dirintis AS sejak 1945. Proyek Virtual network yang dikembangkan DARPA pada 1974 menjadi dasar bagi pengembangan internet yang kita nikmati sekarang. Produk lain seperti Global Positioning System (GPS), semikonduktor, mesin jet, pendingin, reactor nuklir, container kapal, satelit cuaca, dan sistem navigasi sesungguhnya lahir dari R\&D untuk kepentingan militer. ${ }^{28}$

${ }^{28}$ Ibid, halaman 128. 
Posisi Indonesia dalam soal pendanaan R\&D, Pemerintah sebenarnya menyadari bahwa pengembangan industri pertahanan membutuhkan aktivitas penelitian dan perekayasaan. Meski pemerintah membuka kemungkinan pendanaan dari APBN dan sumber pendanaan lain, pendanaan untuk aktivitas ini lebih diserahkan ke Industri pertahanan, sesuai dengan Undang-Undang Nomor 16 Tahun 2012 Pasal 43 menyatakan bahwa Industri pertahanan diminta menyediakan paling rendah 5 persen dari laba bersih untuk kepentingan penelitian dan pengembangan.

Undang-Undang Nomor 16 Tahun 2012 tentang Industri Pertahanan juga mengatur bahwa industri pertahanan diminta menyediakan paling rendah 5 persen dari laba bersih untuk kepentingan penelitian dan pengembangan di bidang pertahanan. Anggaran R\&D ini data dibebankan sebagai komponen biaya oleh industri pertahanan. Tapi ini bukan berarti beban utama untuk menggenjot aktivitas R\&D terletak di pundak industri pertahanan. Undang-Undang juga menegaskan, pelaksanaan R\&D serta perekayasaan dilakukan perguruan tinggi, institusi penelitian dan pengembangan, baik Lembaga pemerintah maupun swasta nasional, TNI/Polri serta Lembaga negara lainnya sebagai pengguna, dan industri pertahanan sendiri. Untuk itu, diperlukan langkah menyinergikan aktivitas dan pendanaan untuk Lembaga lainnya. ${ }^{29}$

\footnotetext{
${ }^{29}$ Pasal 28 Undang-Undang Nomor 16 Tahun 2012.
} 


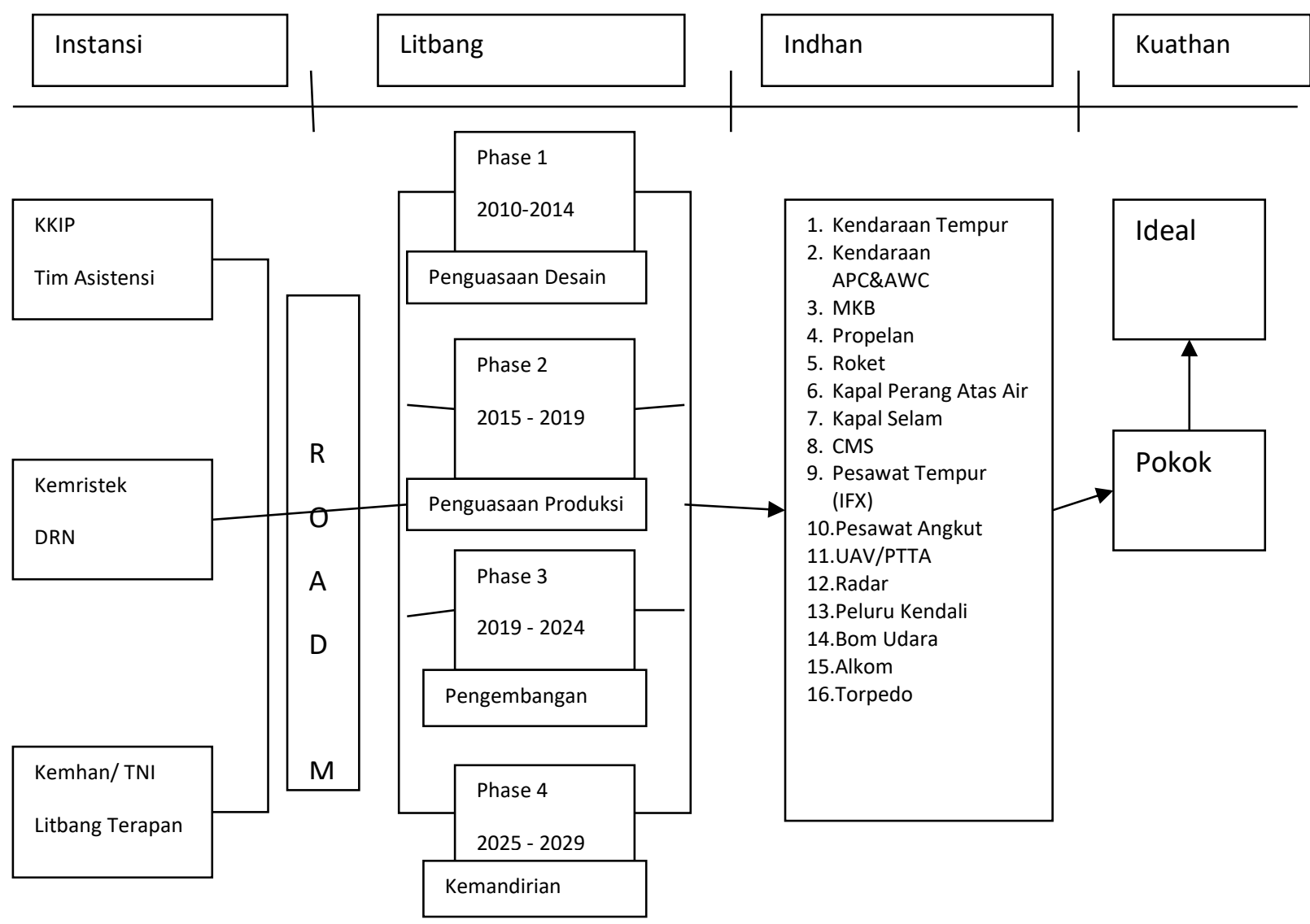

Gambar 4. Cetak Biru Penelitian dan Pengembangan Alutsista (Yusgiantoro, 2014)

Gambar 4 menunjukkan hasil kerja sama antara KKIP, Kemristek dan Kemhan dan TNI dalam membangun cetak biru tahapan yang perlu dilalui untuk mengembangkan alutsista sampai dengan tahun 2024. Cetak biru ini merupakan perpaduan program antara KKIP, kemhan/TNI, dan Dewan Riset Nasional (DRN) yang bergabung secara harmonis dalam rencana pengembangan alutsista. KKIP sebagai pengambil kebijakan dalam industri pertahanan, Kemhan/TNI sebagai pengguna yang memahami rencana pembangunan kekuatan pokok dan kekuatan ideal TNI, dan Dewan Riset Nasional (DRN) berada di bawah koordinasi Kementerian Riset dan Teknologi yang membidangi penelitian dan pengembangan bersifat riset terapan. ${ }^{30}$

${ }^{30}$ Yusgiantoro, op.cit., hal 257. 
p-ISSN : 2541-2345, e-ISSN : 2580-8842

\section{Kekuatan Pertahanan Minimum / Minimum Essential Force (MEF) dan Industri Pertahanan}

Minimum Essential Force (MEF) menetapkan keperluan masing-masing matra di pertahanan nasional : TNI Angkatan Darat, TNI Angkatan Laut, dan TNI Angkatan Udara. Ulasannya tidak hanya mencakup kondisi alat utama pertahanan dan keamanan yang dimiliki ketiga Angkatan tersebut, tapi juga mencakup rencana pengembangan hingga saran atau rekomendasi yang mesti dilakukan untuk mencukup kebutuhan MEF yang telah digariskan.

Jika merunut ke belakang, sebenarnya pemerintah telah menempuh upaya menjadi integrator antara kebutuhan atau tuntutan dari ketiga Angkatan perang dan kemampuan industri pertahanan dalam negeri.

Melalui pembahasan KKIP dan sejumlah stakeholder terkait, dua tahun kemudian lahirlah Undang-Undang Nomor 16 Tahun 2012 tentang Industri Pertahanan. Pada dasarnya peraturan baru ini mengusung spirit untuk memberdayakan industri pertahanan dalam negeri. Dokumen KKIP mencatat tiga arahan strategis dari Presiden yang melihat adanya pertautan kepentingan antara pemberdayaan industri pertahanan dalam negeri dan pemenuhan kebutuhan minimum pertahanan negara, yaitu ${ }^{31}$

Aspek pertama, mewajibkan pengguna dalam negeri memakai produksi dalam negeri untuk alutsista dan non-alutsista. TNI dan Polri serta instansi pemerintah lainnya diwajibkan memakai produksi dalam negeri manakala kebutuhan tersebut dapat diproduksi oleh kita sendiri. Aspek kedua, manakala harus membeli dari luar negeri, persyaratannya harus dipastikan bahwa industri di dalam negeri belum mampu memproduksinya mengingat adanya kebutuhan teknologi tinggi.

Khusus untuk pembelian dari luar negeri harus ditambah persyaratan transfer teknologi dan offset dari negara pemasok kepada industri pertahanan dalam negeri. Aspek penting ketiga, pembelian dari luar negeri tidak boleh mendikte secara politik terhadap negara dalam membeli peralatan militer.

${ }^{31}$ Dokumen KKIP dalam kuliah di Prodi Ekonomi Pertahanan Universitas Pertahanan, disampaikan 24 Maret 2014. 
Kementerian Pertahanan sebagai Pembina industri pertahanan berkepentingan memberikan peluang kepada industri pertahanan dalam ngeri untuk memasok kebutuhan. Bahkan, Kementerian Pertahanan mendorong industri pertahanan dalam negeri untuk bisa mengekspor produknya ke luar negeri. Kemampuan industri dalam negeri kita Sekarang ini sudah pada tingkat teknologi menengah. Artinya, industri pertahanan kita sudah dapat membuat dan sudah digunakan oleh TNI.

MEF lahir bukan dalam ruang dan waktu berbeda dengan industri pertahanan. Jika ditilik lebih lanjut, sejatinya dengan MEF itulah industri pertahanan dalam negeri dapat menjadikannya batu tumpu (stepping stone) dalam menyusun rencana kerja jangka pendek hingga jangka panjang. Di satu sisi, secara regulasi keberadaan BUMN industri pertahanan telah dipayungi oleh Undang-Undang Nomor 16 Tahun 2012; di sisi lain, pengelola industri pertahanan dapat menjadikan arahan Kementerian Pertahanan atas pemenuhan tuntutan MEF sebgai referensi utama. Sisi strategis yang harus dikejar tak lain adalah sinkronisasi antara kebuthan pengguna dan kemammpuan industri pertahanan alias kesatuan yang ada di TNI. Di sinilah urgensi dari upaya penyelarasan kebutuhan masing-masing Angkatan dalam TNI (Angkatan Darat, Angkatan Laut, dan Angkatan Udara) dengan kemampuan produksi dari industri pertahanan dalam negeri menjadi sangat kritikal.

Setidaknya ada delapan isu yang menjadi titik kritis terkait dengan MEF, di antaranya mencakup : ${ }^{32}$

a) Aspek penentuan ancaman;

b) Aspek perencanaan kebutuhan alutsista;

c) Aspek mekanisme penyelenggaraan pengadaan alutsista;

d) Aspek kebijakan anggaran dari pemerintah;

e) Aspek pengambilan keputusan dari masing-masing Angkatan dalam TNI;

f) Aspek kemampuan produksi, mutu dan jaminan pemeliharaan oleh industri pertahanan dalam negeri;

${ }^{32}$ Bahan kuliah untuk mata kuliah Industri Pertahanan di Prodi Ekonomi Pertahanan Universitas Pertahanan, disampaikan 12 Maret 2014. 
p-ISSN : 2541-2345, e-ISSN : 2580-8842

g) Aspek personel pengguna alat utama sistem persenjataan;

h) Penyelarasan pertumbuhan organisasi, modal, teknologi, dan sumber daya manusia dari industri pertahanan dalam negeri.

Menelisik delapan aspek kritis dalam sinkronisasi antara tuntutan kebutuhan sesuai dengan pokok-pokok pikiran dalam MEF dan kapasistas industri pertahanan dalam negeri, maka perlu keberpihakan atau affirmative policy dari penyelenggara negara. Kekuatan, determinasi, dan kreativitas dalam pengambilan keputusan inilah yang akan melahirkan respons positif bagi kemampuan industri pertahanan dalam negeri untuk menjadikan MEF sebagai batu tumpu pertumbuhan usahanya..

\section{PENUTUP}

Pokok-pokok pikiran mengenai pembangunan kemandirian industri pertahanan Indonesia dalam Undang-Undang Nomor 16 Tahun 2012 meliputi Pembentukan dan penguatan KKIP (Komite Kebijakan Industri Pertahanan), Komite Kebijakan Industri Pertahanan yang disingkat dengan KKIP dibentuk berdasarkan Pasal 18, yang memiliki tugas untuk mengkoordinasikan kebijakan nasional dalam perencanaan, perumusan, pelaksanaan, pengendalian, sinkronisasi, dan evaluasi Industri Pertahanan. Pembinaan industri utama dan pendukung dalam industri pertahanan terdiri atas industri alat utama, industri komponen utama dan penunjang, industri komponen dan pendukung (perbekalan), serta industri bahan baku. Pemerintah sudah mengatur bahwa BUMN pertahanan menjadi industri alat utama sekaligus pemandu utama (lead integrator) yang menghasilkan alat utama sistem senjata dan/atau mengintegrasikan semua komponen utama, komponen, dan bahan baku menjadi alat utama.

Pendanaan industri pertahanan diwujudkan berupa beberapa komitmen pendanaan pemerintah terhadap industri pertahanan seperti diatur dengan kerangka besarnya, pemerintah menetapkan keranga pembiayaan jangka panjang untuk industri pertahanan milik negara melalui Anggaran Pendapatan dan Belanja Negara (APBN) atau instrument pembiayaan lain Mandiri dalam membuat/memproduksi dengan menekankan bahwa kemandirian dalam membuat alat-alat pertahanan sendiri adalah tujuan besar yang hendak dicapai bangsa Indonesia. Meski kemandirian total sulit dicapai, langkah menuju kemandirian industri pertahanan kita tidak boleh surut 
p-ISSN : 2541-2345, e-ISSN : 2580-8842

sebagaimana diamanatkan dalam Pasal 50 ayat 1 Undang-Undang Nomor 16 Tahun 2012. Kekuatan pertahanan minimum/Minimum Essential Force (MEF) dan Industri Pertahanan diwujudkan berupa kekuatan, determinasi, dan kreativitas dalam pengambilan keputusan inilah yang akan melahirkan respons positif bagi kemampuan industri pertahanan dalam negeri untuk menjadikan MEF sebagai batu tumpu pertumbuhan usahanya.

\section{DAFTAR PUSTAKA}

\section{Buku}

Hartanto, Agus. Kajian Kebijakan Alutsista Pertahanan dan Keamanan Republik Indonesia. Jakarta : LIPI Press, 2013.

Karim, Silmy. Membangun Kemandirian Industri Pertahanan Indonesia. Jakarta : Kepustakaan Populer Gramedia, 2014.

Supriyatno, Makmur. Tentang Ilmu Pertahanan. Jakarta : Yayasan Pustaka Obor Indonesia, 2014.

Yusgiantoro, Purnomo. Ekonomi Pertahanan : Teori \& Praktik. Jakarta : PT Gramedia Pustaka Utama, 2014.

\section{Jurnal}

Ahmad Jazuli, "Pembangunan Pertahanan dan Keamanan Demi Penegakan Hukum di Indonesia: Kewibawaan Suatu Negara," Jurnal Penelitian Hukum DE JURE 16, No. 2(Juni2016), Badan Penelitian dan Pengembangan Kemenkumham, 2016, Jakarta. DOI: http://dx.doi.org/10.30641/dejure.2016.V16.187-199.

Faris Al-Fadhat dan Naufal Nur Aziz Effendi, "Kerjasama Pertahanan IndonesiaKorea Selatan: Kedaulatan Maritim dan Transfer Teknologi dalam Pengadaan Kapal Selam DSME 209/1400," Jurnal Ketahanan Nasional 25, No. 3 (Agustus 2019), Universitas Gadjahmada, 2019. Yogyakarta. DOI: 10.22146/jkn.48822.

Helmi Tachejadi Soerjono, Muhamad Nur Affandi, Soni Akhmad Nulhaqim, "Perkembangan Alutsista Satuan Infanteri Pada Prioritas Pembangunan Minimum Essential Force (Mef)," Jurnal Kolaborasi Resolusi Konflik 01, No. 1 (September 2019). Universitas Padjadjaran, 2019, Bandung.

Ian Montratama, "Strategi Optimalisasi Pengadaan Sarana Pertahanan Bagi Industri Pertahanan Indonesia," Jurnal Pertahanan 04, No. 3 (Desember 2014), Kementerian Pertahanan RI, 2014, Jakarta. DOI: http://dx.doi.org/10.33172/jpbh.v4i3J.342.

Lukman Fahmi Djarwono, "Pembangunan Industri Pertahanan Indonesia: Menuju Pemenuhan Target MEF atau Sekedar Menuju Arm Candy," Jurnal 
p-ISSN : 2541-2345, e-ISSN : 2580-8842

Defendonesia 02, No. 2 (Juni 2017). Lembaga Kajian Pertahanan untuk Kedaulatan NKRI, 2015, Jakarta.

Muradi, "Model Pendanaan Industri Pertahanan dan Peningkatan Sumber Daya Manusia," Jurnal Pertahanan 05, No. 2 (Agustus 2015). Kementerian Pertahanan RI, 2015, Jakarta. DOI: http://dx.doi.org/10.33172/jpbh.v5i2.365.

Pebri Tuwanto, "Politik Pembangunan Industri Pertahanan Nasional di Era Global," Jurnal Gema Keadilan 02, No. 1 (September 2015), Universitas Diponegoro, 2015, Semarang DOI: $\underline{10.3592 / 2}$.

\section{Undang-Undang}

Undang-Undang Nomor 16 Tahun 2012 tentang Industri Pertahanan.

\section{Artikel dan Lain Lain}

Bahan Kuliah untuk mata kuliah Industri Pertahanan di Prodi Ekonomi Pertahanan Universitas Pertahanan, disampaikan 12 Maret 2014.

Bitzinger (ed). The Modern Defense Industri, dalam (Silmy Karim, Membangun Kemandirian Industri Pertahanan Indonesia. Jakarta: Kepustakaan Populer Gramedia, 2014.

Dokumen KKIP dalam kuliah di Prodi Ekonomi Pertahanan Universitas Pertahanan, disampaikan 24 Maret 2014.

Kathleen A. Walsh, "The Role, Promise, and Challenges of Dual-Use Technologies in Nasional Defense", dalam Richard A. Bitzinger (editor), The Modern Defense Industri, ABC-CLIO, LLC, California, 2009.

Komite Kebijakan Industri Pertahanan (KKIP), "Paparan Menteri Pertahanan Selaku Ketua Harian KKIP pada Sidang Pertama KKIP”, materi presentasi (Surabaya, 12 Maret 2014).

Rapat Harmonisasi RUU Revitalisasi Indhan pada Rabu, 6 Oktober 2010 di Kem Huk \& HAM dalam Kuliah Mata Kuliah Industri Pertahanan Prodi Ekonomi Pertahanan Universitas Pertahanan 8 Maret 2014. 